\title{
TOVÁRNÍ KOMÍNY - NEVÍTANÍ SOUSEDÉ, ZNEČIŠŤOVATELÉ OVZDUŠí A HYZDITELÉ PANORAMAT
}

\author{
MARTIN VONKA
}

\section{FACTORY CHIMNEYS: UNWELCOME NEIGHBOURS, AIR POLLUTERS, AND SKYLINE WRECKERS}

Nowadays, factory chimneys are seen as a valuable part of our industrial heritage that deserves adequate protection. In the past, however, chimneys also had a negative impact on their surroundings: they were an unwelcome addition to urban environment, whose inhabitants they irritated with their smoke, and in some cases clearly disturbed the urban skyline.

Keywords: factory chimneys - smoke irritation - architecture - landmark - industry

DOI: $10.14712 / 23365730.2018 .40$

\section{Úvod}

Tovární komíny vznikly jako ryze praktické a funkční stavby - aby měla továrna energii, potřebovala kotelnu a komín. Komín by byl bez kotelny zbytečný a kotelna by zase nefungovala bez komína - tato synergie tak společně utvořila energetické srdce továrny. Funkce komínu byly v principu dvě: poskytování tahu, čímž do topeniště kotle proudil vzduch potřebný pro proces hoření, a odvádění vzniklých zplodin do výšin, kde se vhodně rozptylovaly a byly co nejméně lidskému zdraví na škodu. A jsou to právě tyto dvě funkce vysokých a zdaleka viditelných staveb chrlících špinavý kouř, jejichž důsledky se staly trnem v oku obyvatel a jejich nevítanými sousedy.

Vysoké komíny začaly významně měnit horizonty lidských sídel. Komíny ukazovaly města jako průmyslová a moderní, a byly to tak výrazné dominanty, že často předčily svojí výškou věže kostelů a katedrál. Začala nová epocha - továrna se stala novodobým chrámem a komíny jejich věžemi (obr. 1).

Postoj lidí k továrním komínům nám mohou pomoci poodhalit zmínky v dobovém tisku. Jednak média hojně informovala o technických parametrech staveb - přeci jen postavit vysokou štíhlou konstrukci bylo umění a komínáři se stali obdivovanými a respektovanými mistry svého oboru. Noviny často obdivně (byt’ zpravidla jen v krátké zmínce) referovaly o tom, kde a jak vysoký komín byl postaven, jak je široký a kolik cihel bylo na stavbě spotřebováno. Nicméně většina tuctových komínů této pozornosti unikla a spíše bojovala při výstavbě i poté během provozu se stížnostmi, že obtěžují kouřem, zahlcují město popílkem a sazemi a hyzdí své okolí. 


\section{Obtěžování kouřem}

Negativní dopad kouře chrleného komíny lidé v období industrializace vnímali špatně, nikdy se s ním ani zcela nesmířili, nicméně jej museli brát jako holou nutnost, která přinášela zřejmý benefit $\mathrm{v}$ podobě technického pokroku, pracovních př́ležitostí a obecného blahobytu. „Kde nekouři komín, nebude upečen žádný chleba, “ pragmaticky glosoval Alexander M. Cay. ${ }^{1}$ Dlužno ale poznamenat, že znatelné znečištění bylo způsobováno lokálními topeništi na uhlí ještě před nástupem průmyslu - Anglie uzákonila první protikouřová opatření již v roce $1773 .{ }^{2}$

Boj s kouřem měl obecně mnoho podob, od legislativních opatření přes technická (například ve formě instalace zařízení pro spalování kouře) až po praktická v podobě práce topiče. ${ }^{3}$ Místní předpisy různě po Evropě často pro dosažení žádaného rozptylu kouře stanovovaly minimální výšku komínů, rakousko-uherské předpisy nařizovaly, že komín musí být postaven tak, aby mohl být $\mathrm{v}$ př́ípadě potřeby navýšen na výšku 30 metrů. Navíc stavební řád ze dne 8. ledna 1889 ustanovil, že topení většího druhu, a zvláště parní kotle, musí být opatřeny př́stroji pro účinné stravování kouře tak, „aby sousedi nebyli kouřem obtěžováni".4 4

Riziko obtěžování kouřem posuzoval úřad při procesu povolení stavby, nicméně když už úr̆ad nic nenamítal proti výstavbě předmětné továrny, tak byl bez problému povolen i komín. Při komisionálním řízení se přezkoumaly parametry technického charakteru, př́ipadně se v povolení dodala podmínka, že kotel bude opatřen zařízením pro spalování kouře, a povolení ke stavbě bylo vydáno.

Když pak nastal případ, kdy lidé začali nahlas vyjadřovat nelibost z kouřícího komína, tak je místní samospráva, vědoma si vy̌̌ších celospolečenských zájmů, odbývala argumenty, že při správném způsobu topení se produkce obtěžujícího kouře významně omezí. Pokud topič bedlivě nedodržoval základní pravidla topení, vycházel z komína hustý dým. Dalším následkem byla skutečnost, že s tímto dýmem odcházela ještě zužitkovatelná energie. Uvádělo se, že ,dobrou prací a řádným topičem“" se může uspořit až 20 \% paliva. ${ }^{5}$

Uved'me si zajímavý př́klad z Mladé Boleslavi. V údolí řeky Jizery vznikly postupně tři komíny, které v 19. století patřily mezi jedny z nejvyšších v rakousko-uherské monarchii. Nejvyšší z nich - osmdesátimetrový obr patřil lihovaru a lučební továrně továrníka Lederera. A právě tato továrna ve městě negativně proslula jako silný znečišt'ovatel, což bylo dáno navíc její nevhodnou polohou na návětrné straně města.

Už dva roky po založení továrny v roce 1875 si nájemce místního hostince Josef Polivka stěžoval, že „,mour od kouře z komína továrny Lederera na Podolci lítá, stoly, podlaha a nábytek vi̊bec pokreje a i hostům v zahradě do piva a jídel padáa" ${ }^{6}$ A nejen hospodský byl nespokojen. Celá řada obyvatel začala při převládajících západních větrech pocit’ovat, jak je celé město nepříjemným zápachem obtěžováno. A to ještě nestál již zmíněný vysoký

1 Bernhard Denscher, Symbol der Industrie: Der rauchende Schlot, Austrian posters, <www.austrianposters.at> (1.3. 2017).

2 Karel LéDL, Odkouření měst, Plyn, voda a zdravotní technika 6/6,1937, s. 320-321.

3 František ŠPATNÝ, Naučení, jak maji topiči parni kotle topiti, Průmyslník 9-10, 1871, s. 185-189.

4 Zákon ze dne 8. ledna 1889, č. 5. zemského zákona, jímžto se vydává Stavební rád pro království České, vyjimajic obce, pro které platí stavebni rád ze dne 10. dubna 1886 č. 40 zemského zákona.

5 Vincenc ŠImERKa, Parni kotly a stroje a jejich obsluha, třetí vydání, Plzeň 1886, s. 79.

6 SOkA Mladá Boleslav, fond Okresní úrad Mladá Boleslav, k. 1 a 2. 
komín. Ten byl postaven v letech $1882-1883$ a situaci př́liš nepomohl. Po zprovoznění komína se rychle opět ozvali nespokojení občané, tentokráte formou petice. Nechali se slyšet, že Lederer si posměšně navzdory všem ustanovením zákona a vzdor všem zákazům dovoluje „kaziti tisícuim obyvatelì mladoboleslavských to nejdražši na světě - zdraví zahaluje a otravuje atmosféru v městě dle své libovůle mraky smrdutého dýmu, jenž vali se z jeho velkého komínu, jenž žádného přiměreného tahu nemá, př́mo do ulic a domů městských". Například během přibližně jednoho roku (konkrétně pak od 7. srpna 1885 do 4. října 1886) zaznamenala městská policie a městské radě udala 212 př́ípadů, kdy tzv. Ledererova hnojírna rozšiřovala hnusný zápach. Dochované archiválie pak ukazují marný boj úřadů a obyvatel proti obtěžování kouřem ještě na konci 19. století (obr. 2). ${ }^{7}$ Velice podobné problémy panovaly i v Praze v př́padě lihovaru na Zlíchově, který založili Samuel Fischel a Adolf Resembau v roce 1880. I zde zamořoval provoz údolí řeky Vltavy a občané proti zápachu brojili celá desetiletí. ${ }^{8}$

V roce 1933, kdy byla v oběhu pětikorunová mince se dvěma koư̌ícími továrními komíny, ražená podle návrhu sochaře Otty Gutfreunda, vyšel novinový článek o dosud stojících pražských komínech, který věrně hovoří za běžná negativa způsobená kouřem. „,Město poctivě se stará, aby odstranilo všechny nedostatky, pokud jde o obtěžování kouřem. Jsou však úseky, kde přece jenom obyvatelstvo trpí. Jde o bydlící v hořejší části Nového města, kolem porodnice, nalezince atd., zkrátka kolem ústavů humanitárních. V zahradě blázince postavili před lety obrovský továrni komín k ústřednímu topení ústavu. Od časného rána, kdy se roztápí, až do odpoledne každou hodinu chrli tento kolos mraky hustého černého dýmu, který hnán západnimi, nebo severními větry, častuje obyvatele domů v Sokolské tř́dě, nebo napadá porodnici a nalezinec. Není možno tu otevírati ani oken, nebot'v několika vteřinách je všechno pokryto sazemi. Neni to jediná závada. V zahradě porodnice postavili si taky takového komínového kamaráda a ten zase pečuje o plíce rodiček a nemluvňat, jakož $i$ dětí ve školách $v$ Sokolské třídě a v dětské nemocnici." "9

O rok dřive sklidilo kritiku i nové strašnické krematorium. I přes upozornění různých autorit na nevhodné umístění v zastavěné části Prahy došlo ihned po zprovoznění na četné stižnosti okolních obyvatel. ${ }^{10}$ Částečně lze vinu přisoudit malé výšce obou komínů, symetricky umístěných po stranách obřadní síně v zadní části traktu, kde se nacházely pece. Architekt Alois Mezera zřejmě nechtěl, aby vysoké komíny narušovaly reprezentativní vjem při pohledu z parteru - architekturu tak zcela jistě nadřadil zdravotním zájmům okolního obyvatelstva.

Historie pamatuje i zdánlivé paradoxy, kdy výstavba jednoho komína mohla přispět $\mathrm{k}$ očistě městského ovzduší. Taková situace nastala například v Brně, kdy nová teplárna společnosti Západomoravské elektrárny (ZME) se stometrovým komínem postavená v letech 1929-1930 nahradila řadu lokálních zdrojů v průmyslových areálech - pro továrníky bylo organizačně i ekonomicky výhodnější si teplo odebírat od externího dodavatele. Snížila se tak produkce sazí, zmírnila se zátěž od rozvážení uhlí a vyvážení strusky a popela z jednotlivých továren po ulicích. „Po uvedeni teplárny do chodu zmizi na siluetě Brna asi

7 SOkA Mladá Boleslav, fond Okresní úřad Mladá Boleslav, k. 1 a 2.

8 Zlíchovský lihovar a-Mladá Boleslav, Národní listy, č. 117, 16. 5. 1881, s. 2.

9 Kamarádi - komínoví, Národní listy, č. 131, 13. 5. 1933, s. 5.

10 Nevhodné umistěni nového krematoria, Národní listy, č. 124, 4. 5. 1932, s. 3. 
100 továrních kominů,“ psalo se na počátku roku 1930. Nicméně realita byla trochu jiná, kouřit ustala nesjpíš třetina z původní proklamace (obr. 3). ${ }^{11}$

Za dob socialismu kouř́íi komíny, ty plíce továrny, nicméně symbolicky přerostly ve znamení lepších zítřků a ukazatel plnění plánu. Na ochranu životního prostředí se ohledy moc nebraly, což věrně dokresluje i oblíbená dětská říkanka Františka Hrubína: „Z komínů se kouří, slunce oči mhouři. Mhuř si oči, mhuř, kdyby se z nich nekouřilo, bylo by nám hůr̆!"12

Přesto se od sedmdesátých let 20. století symbolika kouřícího komína postupně přesunula na úroveň ekologické hrozby. Komín, ten na první pohled viditelný znečištovatel, se pochopitelně stal terčem kritiky nově vznikajících ekologických skupin. A není náhoda, že později začali členové mezinárodní ekologické organizace Greenpeace komíny zneužívat a skrze plachty vyvěšené na jejich dřících hlásat do světa svá ekologická hesla.

V 21. století éra sebevědomě kouřících komínů skončila. Nová doba hlásá hesla jako udržitelný rozvoj a environmentální dopady. Kouř z komínu lze beze studu využít akorát tak za účelem umělecké performance. Jedna taková se udála v únoru 2008 v Helsinkách. Jednalo se o unikátní projekt, který velice př́hodně a s ekologickou myšlenkou dokázal zapojit funkční komín do života veřejnosti. Pro umělecký projekt s názvem „Nuage Vert“ (v překladu zelený mrak) byl využit komín místní elektrárny Salmisaari. V principu šlo o interaktivní hru pro místní obyvatele, kdy se do kouře laserem po dobu jednoho týdne promítal tlustý obrys v podobě mraku kopírujícího konturu dýmu, prričemž jeho velikost se zvětšovala s aktuálně klesajícím výkonem elektrárny. A tak lidé informovaní o tomto projektu vypínali doma každou noc spotřebiče a šli se ven dívat, jaký dopad mají jejich úsporná opatření v podobě postupně rostoucího mraku. Projekt byl vyhlášen za environmentální uměleckou instalaci roku ${ }^{13}$ a později se rozšřřil i do jiných měst.

\section{Hyzdění panoramat}

Čadící komíny nebyly zhýčkanými měštany vnímány jako okrasa měst. Však také anglický architekt August W. Pugin již v roce 1836 ve svém díle Kontrasty provokoval průmyslovými motivy lidi. Na jednom jeho vyobrazení staré tradiční církevní dominanty zcela zastínily kouřící trubky. ${ }^{14} \mathrm{Z}$ nich valící se kouř poukázal na hrozivé poselství o nastolení nového dynamického řádu, kde tradičního boha vzývaného věžemi katedrál vytlačuje bůh průmyslový sedící na trůnu neseném komíny. Netrvalo dlouho a Puginova vize byla zhmotněna. Právě v roce jeho smrti (1852) zachytil malír William Wyld na svém obraze Manchester from Kersal Moor kolébku průmyslové revoluce Manchester. Romantická zelená krajina na něm plynule přechází v město dýmem zahalené a původní církevní dominanty splývají s lesem komínů.

Oproti obtěžování kouřem nemělo negativní narušování panoramatu oporu v legislativě. Úřady z výše zmíněných pohnutek mnoho proti stavbě komínů nenamítaly, a tak bylo na lidech a spolcích, aby proti začouzeným komínům ve svém okolí brojili - napríklad pomocí tisku. Boj to byl vskutku marný, o čemž lze dnes najít celou řadu zmínek.

11 Martin Vonka, Tovární komíny: funkce, konstrukce, architektura, Praha 2014, s. 191.

12 František Hrubín - Adolf ZÁBranskÝ, Je nám dobře na světě, Praha 1951, báseň Továrna na slunci.

13 Laura AALto, Voimalaitosrakentamista ja näkymiä tulevaisuuteen, Helsingin Energia, 2009, s. 50.

14 A. Welby Pugin, Contrasts, or, a Parallel Between the Noble Edifices of the Fourteenth and Fifteenth Centuries, and Similar Buildings of the Present Day, London 1836. 
Proti hyzdění historických siluet měst se dalo částečně bojovat kvalitní architekturou průmyslových staveb nebo i tzv. maskováním komínů. Ve viktoriánském období se v Británii stal velice oblíbeným styl tradičních italských věží, respektive zvonic zvaných kampanila. Dalším běžným principem bylo komplexní pojetí komína společně s př́slušnou průmyslovou budovou v jednotném architektonickém slohu. Hned dva př́klady doposud stojí v Postupimi, kde pruský architekt Friedrich Ludwig Persius navrhl ve čtyřicátých letech 19. století dvě parní kotelny pro čerpání vody v místních parcích Sanssouci a Babelsberg jednu v podobě islámské mešity s komínem, který vypadal jako minaret, druhou jako hrad, kde štíhlá věž s cimbuřím posloužila jako komín. Podobný komín s cimbuřím existuje i u nás, a to v Klamově huti v Blansku. ${ }^{15}$

Při maskování komínů se užívala možnost schovat komín do konstrukcí ostatních průmyslových objektů. Cílem návrhu se tak stalo vizuální potlačení komína ve stávajících strukturách a zmírnění společenského odporu proti výstavbě nového komína. Mezi typické př́pady patří věžové vodojemy, v Praze se zrodily hned dvě ukázkové realizace.

V roce 1886 se plánovala výstavba parní přečerpávací stanice v zahradách pod Strahovským klášterem, ale místním se to, slovy tehdejšího tisku, nelíbilo: „Na mistě tom vystavěn býti musí vysoký komín, kterýž rušiti bude krásný pohled na kláśter strahovský a pokazí mimo to ten trošek zdravého vzduchu na Malé stranè. "16 Radní naproti tomu argumentovali tím, že komín bude postaven v podobě vkusné věžičky, ve které ho nikdo nepozná, a kouruit také nebude, stejně jako u Horschitzova vodojemu na Karlově. Nakonec byla čerpací stanice postavena $v$ roce 1888 na Letné, a to společně s novým vodojemem. Uplatnila se zde právě původní strategie radních - komín se ukryl do neorenesanční zdobné věže vodojemu podle návrhu Jindřicha Fialky a parní kotle byly doplněny zařízením na úplné spalování kouře. Nutno ale dodat, že existují dobové záběry, na kterých se z ukrytého komína znatelně koư̌rí. Stejný př́stup „Zamaskování“ byl o pár let později (1891) aplikován ještě u vodárenské věže na Vinohradech dle návrhu Antonína Turka (obr. 4). ${ }^{17}$

Takovéto realizace bývaly ale spíše výjimečné, tisíce továrních komínů měly typický tvar konické trubky více či méně dozdobený tvarovanými hlavicemi či ornamenty z barevných cihel. Takovýto typický komín stál např́ílad na levém břehu řeky v Odkolkově mlýnu na Kampě. Celá léta narušoval pohled na Malou stranu a Hradčany, zlom nastal po požáru mlýna v roce 1896 a Pražané si oddechli, když byl komín následně zbořen. ${ }^{18}$ Nicméně dnes historické panorama nadále doplňuje čtyřicet metrů vysoký komín postavený pro tiskárnu A. Haase, nacházející se hned naproti přss řeku. V roce 2005 byl opraven a na základě požadavků památkové péče musel být zachován i jeho vzhled poznamenaný výkvěty. Komín dodnes kouríí, byt' jde již jen o bílý dým z plynové kotelny.

V roce 1927 bylo ohroženo panorama Emauzského kláštera novým, asi třicet metrů vysokým komínem nemocniční prádelny. Vše věrně popisuje dobový článek v Národních listech: „Je zcela nepochopitelno, jak povolaní ćinitelé netečně hledí k hrozícímu úplnému zničeni jedinečného panorama Emaus od Rašinova nábřeží. V poslednich dnech staví se na nábřeži zástupy obecenstva a súžasem hledí, jak u vznosných věži emauského kostela

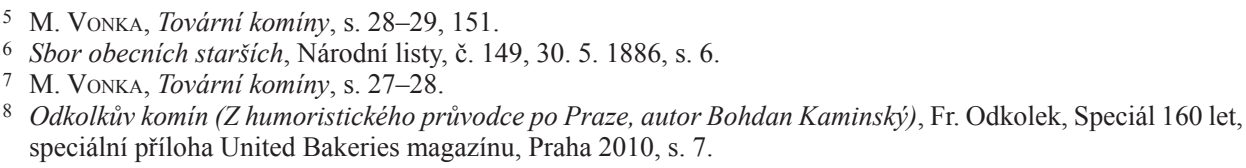


vyrůstá obrovský, ohyzdný továrni komín. Aby bylo zničení pohledu úplné, stavi se továrni komín z bilých cihel, a to snad proto, aby i bezděčného pozorovatele upozornil na svoji jsoucnost. Celá věc vypadá jako nemožná pohádka, ale bohužel je až př́liš pravdivá. Komín se prostě stavi ve všeobecné nemocnici a je tak virtuosně umistěn, že přesně zapadá do zminěného panorama. Je ku podivu, že totéž ministerstvo, které prísně dbalo k stavebnímu zachování panoramatu, dovolilo nyní jeho úplné zničení. Stavitelé komínu sami se nějak zalekli svého díla a nyni v půli stavby práci zastavili. Nyní snad se bude jednat o to, co sbourat, komín nebo Emausy?"19

Naopak v Brně o pár let později při demolici komína jásali: „Včera dopoledne padlo zase kus starého škaredého Brna. Na Dobrovského ulici strašil dlouhá léta v sousedství krásných modernich domů vysoký černý komín, tyčící se nad starou, začouzenou a přikrčenou cihelnou, $v$ niž se již dávno nepracovalo, ale kam si chodila policie pravidelně a na jisto pro podezřelá individua, která se právě nepodařilo najít v lokálech.... Pěkné čtvrti pod Kraví horou a Brnu dostalo se zase kus starého stavebního mista, kde se již také na jaře začne stavět." $" 20$

V Hradci Králové si zase oddechli při demolici komína místního pivovaru v historickém centru v roce 1965: „Válec komína se stane zbytečným, což zase prospěje i klasickému panoramatu gotických věží, kde dosud kouřicí komín rušivè působil.“"21

Postupem času ale komíny přeci jen pomalu, ale jistě srůstaly s městskými celky a okolní krajinou. Po skončení druhé světové války situaci výstižně popsal Rudolf Hrdlička: „Dnes už nikdo nelká nad ,zkaženou 'siluetou měst, v niž se vedle štíhlých věži chrámů a malebných střech palácủ rýsuji tovární komíny. Čas sladil křehký pưvab starobylých staveb se strohými liniemi začazených stožárů práce. Takový je svět. Krása bez chleba nestači k udrženi života. Továrny vtáhly vitězně do měst a staly se baštami novodobých bojovnikư práce."22

\section{Současnost}

Továrny a komíny vytvořili lidé. Nyní jsme v době, kdy většina starých komínů je odstavena a tyto nefunkční stavby naopak utváŕí člověka. Jsou v našem životním prostoru, působí na nás, evokují různé pocity a ovlivňují náš pohyb a pobyt v daném místě. Tato interakce může být v mnoha ohledech nejen pozitivní, ale i negativní, neutrální či lhostejná - je to individuální. Častokrát se lze setkat i s lidmi, kteří komíny ve svém prostředí vůbec nevnímají. Což je paradox s ohledem na to, jak dominantní komíny bývají. Jiná skupina lidí v komínech nadále vidí symbol znečištění, nevkusu a narušitele jejich výhledu z okna.

Tovární komíny postupně prererstají v technické a historické ikony, které si zasluhují patřičné ochrany jako nedílné součásti našeho kulturního dědictví. Komíny mají silný potenciál posloužit jako symbolický svědek minulosti, nabízí se řada možností, jak nefunkční komíny zapojit do stávajících i nových městských struktur. Je tak jen na nás, zda z dř́ve nevítaných sousedů uděláme vzácný klenot s př́během a vítaného společníka autenticky se utvárejícího genia loci toho kterého místa (obr. 5).

19 Panorama Emaus v nebezpečí, Národní listy, č. 87, večerní vydání, 14. 4. 1927, s. 1.

20 Smrt starého komína, Lidové noviny, č. 640, ranní vydání, 22. 12. 1935, s. 7.

21 Nepotřebný komín, Pochodeň, č. 288, 2. 12. 1965, s. 3.

22 Rudolf HrdLIČKa, Stožáry práce, Květen, č. 14, 4/1946. 


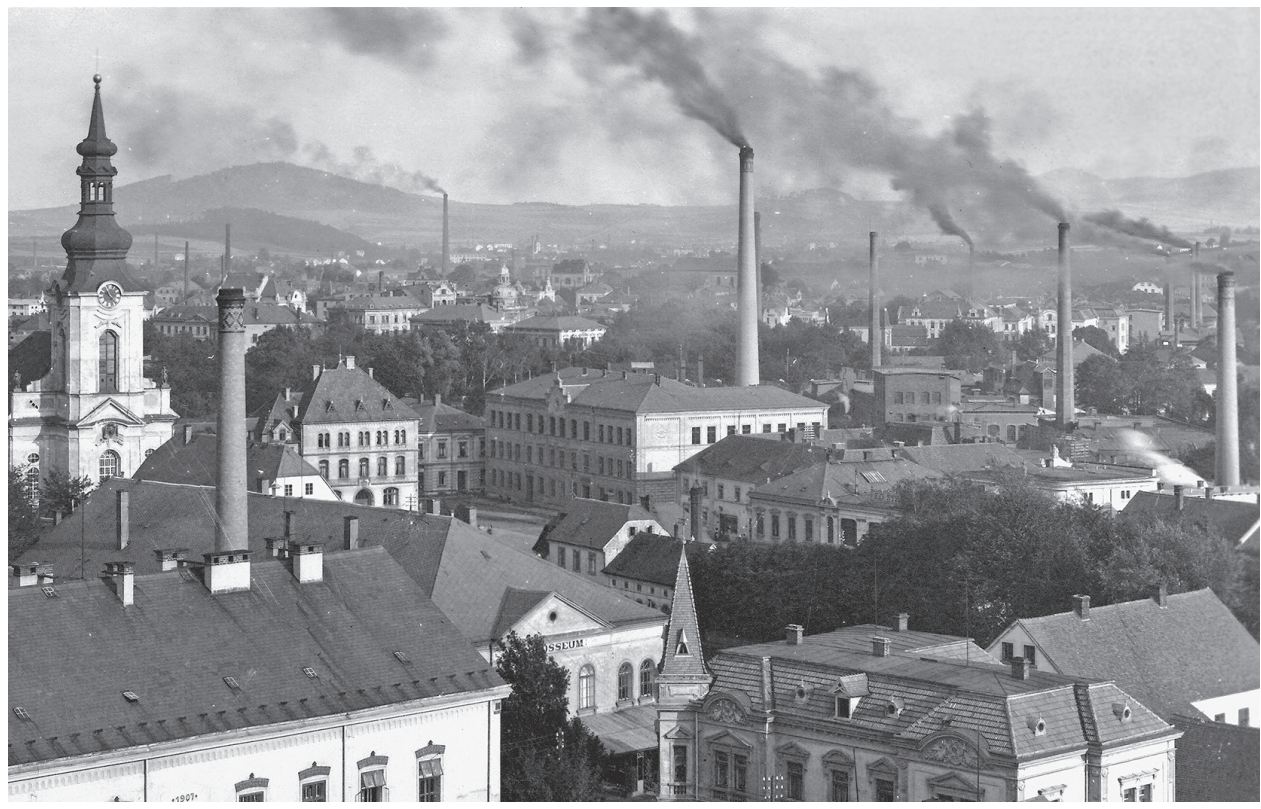

Obr. 1 Město mládí, zahrad a komínů - Varnsdorf, kolem roku 1935 (dobová pohlednice, archiv autora)

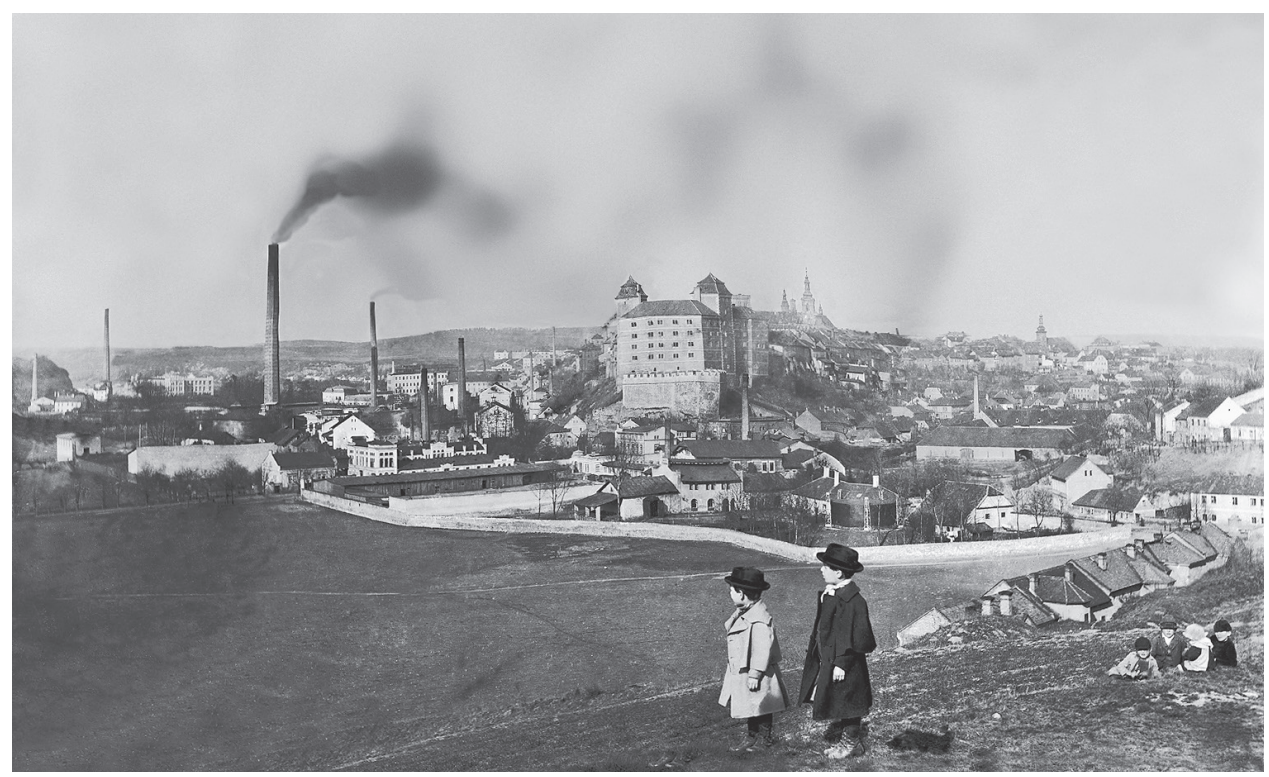

Obr. 2 Továrny v údolí řeky Jizery v Mladé Boleslavi a nejvyšší komín v areálu Ledererovy továrny, zamořující město svým kouřem, nedatováno (Archiv Muzea Mladoboleslavska) 


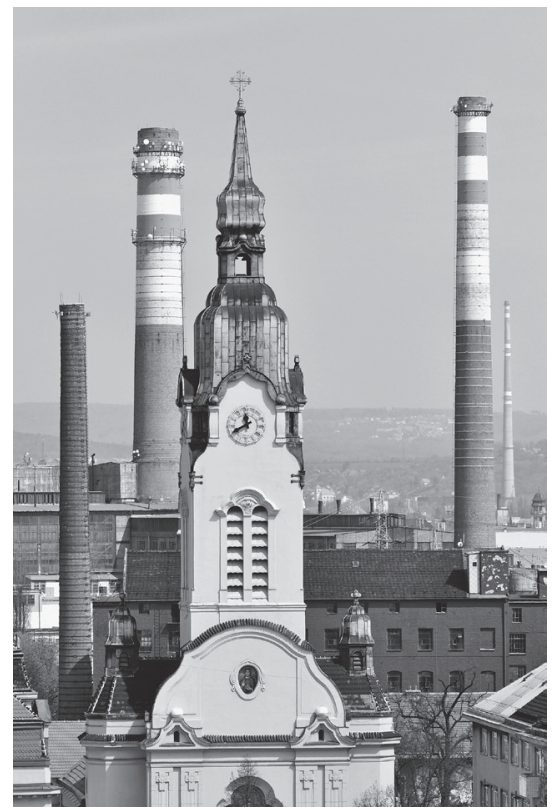

Obr. 3 Nejvyšší zděné komíny v Brně patři místní teplárně Na Špitálce (bývalá ZME) nejstarším komínem v areálu je komín vpravo, 2010 (fotoarchiv autora)

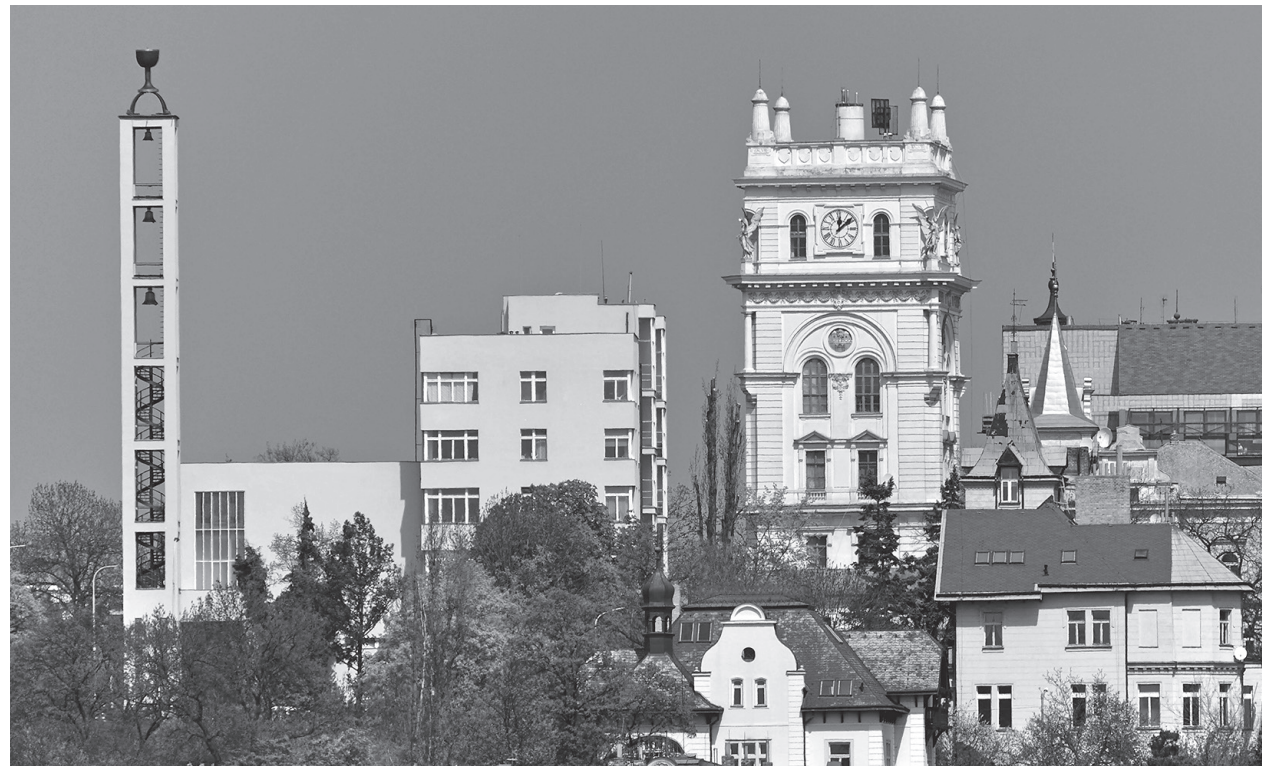

Obr. 4 Neorenesanční věžový vodojem na Vinohradech a jeho zamaskovaný komín umístěný v ose věže, 2010 (fotoarchiv autora) 


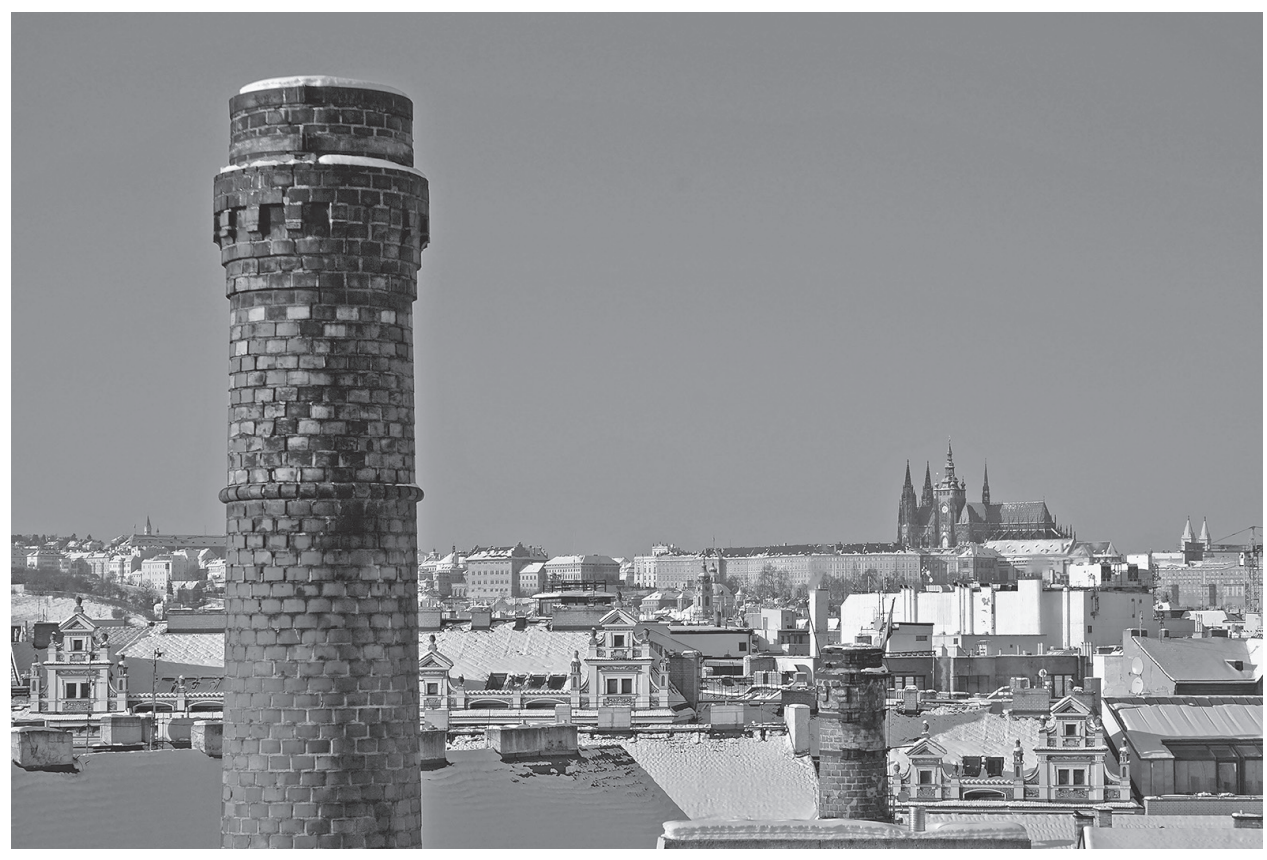

Obr. 5 Hyzditel panoramatu, nebo cenný relikt doby?, 2005 (fotoarchiv autora)

\section{MARTIN VONKA}

\section{Fabrikschornsteine - ungeladene Nachbarn, Umweltverschmutzer und Panoramaschänder}

\section{ZUSAMMENFASSUNG}

Fabrikschornsteine entstanden als rein praktische und funktionelle Bauwerke, als untrennbare Bestandteile von Dampfkesseln. Die Funktion eines Schornsteins war im Prinzip zweierlei: die Gewährung von Luftzug, wodurch die für den Brennprozess nötige Luftzufuhr in die Heizanlage gelangte, und die Abfuhr der entstandenen Brandgase nach oben zu gewährleisten, wo sie sich zerstreuten und die menschliche Gesundheit am wenigsten gefährdeten. Und das sind gerade die beiden Funktionen, deren Folgen den Bewohnern ein Dorn im Auge waren.

Hohe Schornsteine begannen die Horizonte menschlicher Siedlungen bedeutsam zu verändern. Sie zeigten die Städte als Industriestädte und moderne Städte und waren derart dominant, dass sie mit ihrer Höhe oftmals die Höhe von Kirch- und Kathedraltürmen überragten. Es begann eine neue Epoche, die tief in die Wahrnehmung der Öffentlichkeit eingriff - die Fabrik wurde zu einer modernen Kirche und die Schornsteine zu ihren Türmen.

In technischer Hinsicht wurden die Schornsteine als hohe schlanke Konstruktionen bewundert und ihre Erbauer waren respektierte Meister ihres Faches. Nichtsdestoweniger hatten die weithin sichtbaren und rauchenden Bauwerke in der Vergangenheit auch ihre Schattenseiten: sie waren ungebetene Gesellschafter in den Stadtstrukturen, in denen sie ihre Umgebung mit Rauch spürbar belästigten und in manchen Fällen auch das Panorama der Städte störten.

Der Kampf mit dem Rauch hatte für gewöhnlich viele Seiten und reichte von legislativen über technische bis hin zu praktischen Maßnahmen. Demgegenüber fand die negative Störung des Panoramas in der Legislative keine Unterstützung und es kam nur darauf an, wie stark die Stimme des Volkes war. Nichtsdestoweniger speiste 
die örtliche Selbstverwaltung, im Bewusstsein höherer gesamtgesellschaftlicher Interessen, diese Stimmen in der Regel ab, so dass die Ergebnisse bis heute in vielen historischen Stadtteilen sichtbar sind: in Prag, Brünn, Pilsen und anderswo.

Jetzt aber leben wir in einer Zeit, da die meisten alten Schornsteine stillgelegt sind und diese nichtfunktionierenden Bauwerke allmählich zu technischen und historischen Ikonen werden, die als untrennbare Bestandteile unseres kulturellen Erbes entsprechenden Schutz verdienen. Die Schornsteine haben ein starkes Potential, als symbolischer Zeuge der Vergangenheit zu dienen, und es bieten sich zahlreiche Möglichkeiten an, wie diese funktionslosen Schornsteine in die bestehenden oder neuen städtischen Strukturen einzubeziehen sind. Es ist also nur an uns, ob wir aus den früher ungebetenen Nachbarn einen wertvollen Schatz mit eigener Geschichte und einen willkommenen Gesellschafter machen, der authentisch einen Genius loci schafft.

Deutsche Übersetzung Wolf B. Oerter

Martin Vonka

Fakulta stavební ČVUTv Praze

martin.vonka@fsv.cvut.cz 